\title{
Factors influencing the dental caries in pregnant women: a cross-sectional study
}

\author{
Fatores que influenciam a cárie dentária em gestantes: um estudo transversal \\ Factores que influyen en la caries dental en mujeres embarazadas: un estudio transversal
}

Gabriela Bohrer Bolsson

ORCID: https://orcid.org/0000-0002-7114-5173 Universidade Federal de Santa Maria, Brazil

E-mail: gabibolsson@hotmail.com

Jessica Klöckner Knorst

ORCID: https://orcid.org/0000-0001-7792-8032 Universidade Federal de Santa Maria, Brazil

E-mail: jessicaknorst1@gmail.com

Marília Cunha Maroneze

ORCID: https://orcid.org/0000-0002-8704-8319 Universidade Federal de Santa Maria, Brazil

E-mail: mariliamaroneze@hotmail.com

Maísa Casarin

ORCID:https://orcid.org/0000-0002-3750-5091 Universidade Federal de Pelotas, Brazil E-mail: maisa.66@hotmail.com Patrícia Pasquali Dotto

ORCID: https://orcid.org/0000-0003-0114-3305 Universidade Franciscana, Brazil E-mail: ppdotto@yahoo.com.br

Bianca Zimmermann Santos

ORCID: https://orcid.org/0000-0001-5303-8115 Universidade Franciscana, Brazil E-mail: biancazsantos@hotmail.com

\begin{abstract}
Objective: To assess factors associated with the average number of dental caries in pregnant women. Method: Basic research design: This cross-sectional study was performed between January 2017 and December 2018 in Santa Maria, Brazil. Clinical setting and participants: Multistage random sampling resulted in the recruitment of 256 pregnant women from public health centers across the city. Clinical exams and semi-structured questionnaires including demographic, socioeconomic and behavioral questions were performed by trained interviewers. Main outcome measure: The experience of dental caries was evaluated through the mean value of the Decay, Missing, and Filled Surface Index (DMFS) by 4 trained and calibrated examiners. Multilevel Poisson regression models were used to evaluate the influence of different variables on the average number of dental caries. Rate ratio (RR) and respective 95\% confidence intervals were calculated (CI 95\%). Results: The prevalence of untreated dental caries was $62.7 \%$ in the sample, while the mean DMFS index was $10.27( \pm 10.92)$. Women who smoked during pregnancy had a higher mean DMFS (RR 1.41; 95\% CI 1.25-1.57). Furthermore, pregnant women who had poor self-ratings of oral health had a higher average DMFS (RR 1.21; 95\% CI 1.10-1.32). Conclusions: The results showed that older age, ethnicity, fewer years in education and the presence of dental plaque resulted in higher means of DMFS.
\end{abstract}

Keywords: Dental caries; Epidemiologic; Studies; Smoking; Oral health; Pregnancy.

\section{Resumo}

Objetivo: Avaliar os fatores associados ao número médio de cárie dentária em gestantes. Método: Desenho básico da pesquisa: Este estudo transversal foi realizado entre janeiro de 2017 e dezembro de 2018 em Santa Maria, Brasil. Ambiente clínico e participantes: A amostragem aleatória em vários estágios resultou no recrutamento de 256 mulheres grávidas de centros de saúde públicos em toda a cidade. Exames clínicos e questionários semiestruturados incluindo questões demográficas, socioeconômicas e comportamentais foram realizados por entrevistadores treinados. Desfecho principal: a experiência de cárie dentária foi avaliada por meio do valor médio do Índice de Cárie, Ausência e Superfície Preenchida (CPOS) por 4 examinadores treinados e calibrados. Modelos de regressão de Poisson multinível foram usados para avaliar a influência de diferentes variáveis sobre o número médio de cárie dentária. A razão da taxa (RR) e respectivos intervalos de confiança de $95 \%$ foram calculados (IC 95\%). Resultados: A prevalência de cárie dentária não tratada foi de 62,7\% na amostra, enquanto o índice CPO-S médio foi de 10,27 $( \pm 10,92)$. Mulheres que fumaram durante a gravidez tiveram uma média de CPOS mais alta (RR 1,41; IC 95\% 1,25-1,57). Além disso, as gestantes com baixa autoavaliação de saúde bucal apresentaram média de CPOS mais elevada (RR 1,21; IC95\% 1,10- 
1,32). Conclusões: Os resultados mostraram que maior idade, etnia, menor escolaridade e presença de placa dentária resultaram em maiores médias de CPOS.

Palavras-chave: Cárie dentária; Estudos epidemiológicos; Tabagismo; Saúde bucal; Gravidez.

\section{Resumen}

Objetivo: Evaluar los factores asociados con el número promedio de caries dentales en mujeres embarazadas. Método: Diseño de investigación básica: este estudio transversal se realizó entre enero de 2017 y diciembre de 2018 en Santa María, Brasil. Entorno clínico y participantes: el muestreo aleatorio de varias etapas resultó en el reclutamiento de 256 mujeres embarazadas de los centros de salud pública de la ciudad. Entrevistadores capacitados realizaron exámenes clínicos y cuestionarios semiestructurados que incluían preguntas demográficas, socioeconómicas y de comportamiento. Medida de resultado principal: La experiencia de la caries dental se evaluó a través del valor medio del índice de decaimiento, ausencia y superficie llena (DMFS) por 4 examinadores capacitados y calibrados. Se utilizaron modelos de regresión de Poisson multinivel para evaluar la influencia de diferentes variables en el número promedio de caries dentales. Se calcularon la razón de tasas (RR) y los respectivos intervalos de confianza del 95\% (IC 95\%). Resultados: La prevalencia de caries dental no tratada fue del 62,7\% en la muestra, mientras que el índice CPOS medio fue de 10,27 $( \pm 10,92)$. Las mujeres que fumaron durante el embarazo tuvieron un CPOS medio más alto (RR 1,41; IC del 95\%: 1,25-1,57). Además, las mujeres embarazadas que tenían una autoevaluación deficiente de la salud bucal tenían un CPOSO promedio más alto (RR 1,21; IC del 95\%: 1,10 a 1,32). Conclusiones: Los resultados mostraron que la edad avanzada, la etnia, menos años de educación y la presencia de placa dental resultaron en mayores promedios de CPOS.

Palabras clave: Caries dental; Estudios epidemiológicos; Tabaquismo; Salud bucal; Embarazo.

\section{Introduction}

Pregnancy is a very special moment in woman`s life. This period is characterized by intense physiological, hormonal and emotional changes (Codato et al., 2011). Also, women are more susceptible to developing oral diseases such as tooth decay, gingivitis, and periodontitis during pregnancy, particularly in the absence of good oral care.

Dental caries is considered one of the most common dental pathologies in pregnant women (Tonello et al., 2007). Pregnant woman with dental caries is associated with lower oral health-related quality of life (OHRQoL) (Moimaz et al., 2016) as it can cause functional problems such as dental pain and discomfort that affect the routine and well-being of pregnant women (Moimaz et al., 2016).

Several factors can influence the development of dental caries during pregnancy, such as an increase in the number of meals per day, salivary hyperacidity and the negligence of oral hygiene (Melo et al., 2007). Other examples can include socioeconomic, behavioral and psychological factors (Silveira et al., 2015).

Some studies have evaluated the presence of harmful behaviors in pregnant women that lead to worse oral health (Kale et al., 2015; Moise, 2019; Bianchini et al., 2020; Toquinto et al., 2020;) While some psychological aspects, such as selfperception of health and quality of life have been explored (Moimaz et al., 2016; Lamarca et al., 2012; WHO, 2013), the influence of psychosocial and behavioral factors on the occurrence of dental caries in pregnant women is still not well established.

The knowledge of factors that can influence the number of dental caries during pregnancy is important for oral health programs for pregnant women. Furthermore, healthy habits acquired in this period can provide numerous benefits for the health of both the mother and the baby. Therefore, the aim of this study was to investigate which factors are associated with dental caries in pregnant women. We hypothesized that pregnant women with more severe psychosocial or behavioral conditions would present higher averages in the number of dental caries.

\section{Methodology}

The present study was performed based on the Strengthening the Reporting of Observational studies in Epidemiology (STROBE). 


\section{Ethics}

The university's ethics committee approved this project (project number 55197616.7.0000.5306) and informed consent was obtained from all participants.

\section{Design and sample}

This cross-sectional study was performed in Santa Maria, Brazil which comprises 273.489 inhabitants (2389 of which are pregnant women) according to official data provided by local authorities. This study is part of a research project entitled "Oral conditions of pregnant women and their children: a cohort study".

Multistage random sampling was performed across the 8 administrative regions of the city. The primary survey included 18 out of the 30 public health centers present in Santa Maria (WHO, 2013). To ensure that all pregnant women had an equal likelihood of being selected, sample sizes per health center was estimated in proportion to the size of health center. From the 18 centers involved in the study, all pregnant women who sought health care were included in this study until the required sample size was reached for that unit.

The sample size was estimated using the following parameters: $5 \%$ standard error, $80 \%$ power, and $95 \%$ confidence level. As there is no available data about the prevalence of dental caries in pregnant women in Santa Maria, we used an estimated prevalence of $50 \%$, which can be considered the worst scenario as recommended by literature (WHO, 2013). Correction factors of 1.2 for effect design and $30 \%$ for non-response rate were included. Thus, the minimum required sample size was 241 pregnant women. The number of pregnant women recruited $(n=256)$ was larger than the minimum calculated $(n=241)$ as this study utilized the cohort from the larger study mentioned above.

\section{Data collection}

Data collection was performed between January 2017 and December 2018. The data was collected through questionnaires and clinical exams. A trained interviewer conducted face-to-face interviews with the participants. The questionnaire included questions about demographic, socioeconomic and behavioral characteristics.

Clinical exams were performed using standardized criteria for oral health surveys, established by the World Health Organization (WHO, 2013). Clinical exams were executed by 4 trained and calibrated examiners. The training and calibration process for clinical exams was performed following the method described by the World Health Organization in the basic manual of epidemiological surveys (WHO, 2013). Intra-examiner and inter-examiner agreement were obtained through a Kappa test.

Plane dental mirrors, community periodontal index (CPI) probe, and natural and artificial light (WHO, 2013) were used to evaluate all teeth surfaces of pregnant women, with the exception of third molars. All clinical exams and questionnaires were performed in a private room of the health centers.

\section{Variables}

The main focus of this study was to determine the number of dental caries in pregnant women, which was evaluated using the Decay, Missing, and Filled Surface Index (DMFS). The number of teeth surfaces that were decayed, missing or filled were considered in the analysis (WHO, 2013), and the mean DMFS value calculated.

Dental plaque was also evaluated using the Visible Plaque Index (VPI) (WHO, 2013), and participants were dichotomized into two categories: those with either $<15 \%$ of sites with dental plaque, or $\geq 15 \%$ of sites with dental plaque.

Participant self-perception of oral health was evaluated in the questionnaire by asking "How would you rate your overall oral health?" and allowing the following answers: $0=$ excellent, $1=$ very good $/$ good, $2=$ average, $3=$ poor, $4=$ very poor. This was 
then used to dichotomized participants into two groups of perceived oral health; excellent/good ( 0 and 1$)$ or average/poor $(2,3$ and 4).

Behavioral variables were also considered. Frequency of use of dentistry services was assessed via questionnaire with the following question: "How often do you go to the dentist?" with the following answer options $0=$ do not attend, $1=$ once a year, $2=$ twice a year, $3=$ three times a year, and $4=$ more than three times a year. For analysis, the variable was dichotomized into irregular or regular attendance. Information related to smoking habits was also collected, including current smoking practice through the question, "Do you currently smoke?" with the answer options "yes" or "no."

Demographic and socioeconomic characteristics were collected using a semi-structured questionnaire with questions regarding age, ethnicity, education level and family income. Age was collected in years, and participants categorized as <20 years, 20 to 30 years, and $>30$ years. Ethnicity was evaluated based on the criteria established by the Brazilian Institute of Geography and Statistics, and participants were subsequently categorized as white or non-white. Education level was recorded as the number of years of study, and participants dichotomized into two groups; $<8$ years of study, or $\geq 8$ years of study. 8 years was used as the cutoff point as it corresponds to standard number of years for primary education in Brazil. Family income was measured by the Brazilian monthly minimum wage (BMW, R \$937) and categorized into terciles (T) for assessment: T1 (low) $<1$ BMW, T2 (medium) 1-2.5 BMW, and T3 (high)> 2.5 BMW.

\section{Statistical analysis}

Data analysis was performed using Stata Statistical Software: Release 14.1 (StataCorp LP, College Station, USA). Descriptive analysis was used to evaluate the demographic, socioeconomic, behavioral and oral clinical characteristics of pregnant women in Santa Maria. Figure 1 shows the hierarchical model. The mean of DMFS was considered the outcome of ths study.

Figure 1. Theoretical model of the association between the predictive variables and dental caries based in Commission for Social Determinants of Health (Solar; Irwin 2010).

Block 1

\section{Demographic and socioeconomic variables}

Age, race, education and household income

Block 2

Block 3

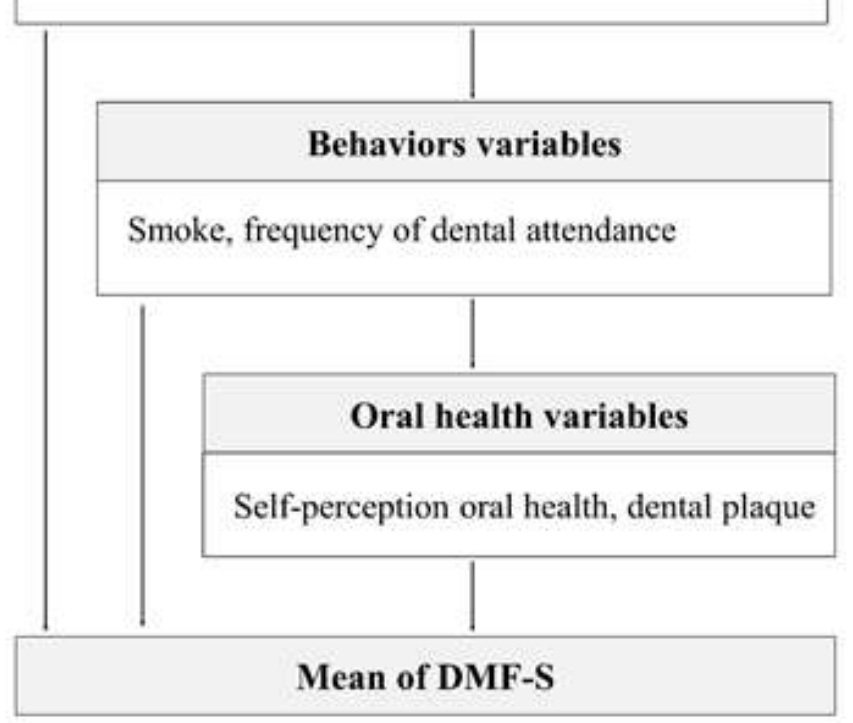

Source: Authors. 
Multilevel Poisson regression models were used to evaluate the influence of different characteristics on the number of dental caries. The multilevel analysis structure considered pregnant women (level 1) nested in the 18 basic units (level 2). Variables with $\mathrm{p}<0.20$ in the unadjusted analysis were considered for multivariate models. The multilevel model used a fixed effect model with a random intercept.

\section{Results}

A total of 256 pregnant women agreed to participate in the study. The average gestation time among the women was 24.60 (SD 9.61) weeks. The average age was 25.42 (SD 6.57) years. Kappa values for inter- and intra-examiner agreement for dental caries ranged from 0.88 to 0.93 , respectively. The prevalence of untreated dental caries was $62.7 \%$ and the mean DMFS index was 10.27 (SD 10.92).

Table 1 presents the sample distribution according to demographic, socioeconomic, behavioral and oral health aspects. Most of the pregnant women were between 20 to 30 years old (60.6\%) and white (56.7\%). Regarding socioeconomic characteristics, most women had completed more than 8 years of study and were in the highest income terciles. Regarding the distribution of DMFS, the highest averages were concentrated in pregnant women who smoked, did not regularly attend the dentist, self-rated their oral health as poor or very poor, and presented dental plaque in $\geq 15 \%$ of the surfaces.

Table 1. Sample distribution and mean of DMFS according to demographic, socioeconomic, behaviors characteristics and oral health measures, Santa Maria, Brazil $(n=256)$.

\begin{tabular}{|c|c|c|}
\hline Variables & n $(\%)$ & DMF-S [Mean $\left(\right.$ SD $\left.^{\mathbf{a}}\right)$ \\
\hline \multicolumn{3}{|c|}{ Demographic and socioeconomic characteristics } \\
\hline \multicolumn{3}{|c|}{ Age } \\
\hline$<20$ years & $49(19.1)$ & $7.3(7.2)$ \\
\hline $20-30$ years & $165(60.6)$ & $8.5(9.2)$ \\
\hline$>30$ years & $52(20.3)$ & $18.5(14.3)$ \\
\hline \multicolumn{3}{|l|}{ Ethnicity } \\
\hline White & $145(56.7)$ & $10.5(10.4)$ \\
\hline Non-white & $111(43.3)$ & $9.9(11.7)$ \\
\hline \multicolumn{3}{|l|}{ Education } \\
\hline$\geq 8$ years of formal education & $198(77.3)$ & $9.4(9.4)$ \\
\hline$\overline{<} 8$ years of formal education & $58(22.7)$ & $13.5(14.8)$ \\
\hline \multicolumn{3}{|l|}{ Household income in $\mathrm{BMW}^{\mathrm{b}}$} \\
\hline Lowest $\left(1^{\text {st }}\right.$ tertile $)$ & $12(4.8$ & $14(15.5)$ \\
\hline Medium ( $2^{\text {nd }}$ tertile $)$ & $190(75.7)$ & $10.0(10.4)$ \\
\hline Hightest $\left(3^{\text {rd }}\right.$ tertile $)$ & 49 (19.5) & $10.9(12.1)$ \\
\hline \multicolumn{3}{|l|}{ Behaviors characteristics } \\
\hline \multicolumn{3}{|l|}{ Smoke } \\
\hline No & $224(87.5)$ & $9.4(10.1)$ \\
\hline Yes & $32(12.5)$ & $16.9(14.6)$ \\
\hline \multicolumn{3}{|l|}{ Frequency of dental attendance } \\
\hline Irregular & $173(68.9)$ & $10.7(11.8)$ \\
\hline Regularly & $78(31.1)$ & $9.2(8.5)$ \\
\hline \multicolumn{3}{|l|}{ Oral health measures } \\
\hline \multicolumn{3}{|l|}{ Self-perception of oral health } \\
\hline Excelent/good & $100(39.2)$ & $8.9(10.4)$ \\
\hline Fair/poor & $155(60.3)$ & $11.3(11.2)$ \\
\hline \multicolumn{3}{|l|}{ Dental plaque } \\
\hline$<15 \%$ of surfaces & $53(20.7)$ & $7.9(10.4)$ \\
\hline$>15 \%$ of surfaces & $203(79.3)$ & $10.9(11.0)$ \\
\hline
\end{tabular}

Values lower than 256 due to missing data. ${ }^{\text {a}} \mathrm{SD}$, standard deviation.

${ }^{b}$ BMW, Brazilian minimum wages.

Source: Authors. 
Table 2 presents the unadjusted association between the different variables and the average DMFS. The demographic and socioeconomic variables associated with the highest averages of the DMFS were higher age, being white, and fewer years in education. Smoking, irregular frequency of dental care, regular or poor self-perception of oral health, and the presence of dental plaque $(\geq 15 \%$ of sites) were associated with a higher mean of dental caries $(\mathrm{p}<0.05)$.

Table 2. Unadjusted association between pregnant variables and mean of DMFS, determined using multilevel Poisson regression.

\begin{tabular}{|c|c|c|}
\hline Variables & $\mathbf{R R}^{\mathrm{a}}(95 \% \mathbf{C I})^{\mathrm{b}}$ & p-value \\
\hline \multicolumn{3}{|c|}{ Demographic and socioeconomic characteristics } \\
\hline Age & & $<0.01$ \\
\hline$<20$ years & 1 & \\
\hline 20-30 years & $1.18(1.04-1.34)$ & \\
\hline$>30$ years & $2.57(2.26-2.92)$ & \\
\hline Ethnicity & & $<0.001$ \\
\hline White & 1 & \\
\hline Non-white & $0.85(0.78-0.92)$ & \\
\hline Education & & $<0.001$ \\
\hline$\geq 8$ years of formal education & 1 & \\
\hline$\overline{<} 8$ years of formal education & $1.30(1.19-1.53)$ & \\
\hline Household income in $\mathrm{BMW}^{\mathrm{b}}$ & & 0.520 \\
\hline Lowest $\left(1^{\text {st }}\right.$ tertile $)$ & 1 & \\
\hline Medium ( $2^{\text {nd }}$ tertile $)$ & $0.83(0.70-0.99)$ & \\
\hline Hightest $\left(3^{\text {rd }}\right.$ tertile $)$ & $0.93(0.76-1.14)$ & \\
\hline \multicolumn{3}{|l|}{ Behaviors characteristics } \\
\hline Smoke & & $<0.001$ \\
\hline No & 1 & \\
\hline Yes & $1.71(1.54-1.90)$ & \\
\hline Frequency of dental care & & $<0.01$ \\
\hline Irregular & 1 & \\
\hline Regularly & $0.86(0.78-0.95)$ & \\
\hline \multicolumn{3}{|l|}{ Oral health measures } \\
\hline Self-perception of oral health & & $<0.001$ \\
\hline Excelent/good & 1 & \\
\hline Fair/poor & $1.27(1.17-1.39)$ & \\
\hline Dental plaque & & $<0.001$ \\
\hline$<15 \%$ of surfaces & 1 & \\
\hline$\geq 15 \%$ of surfaces & $1.24(1.11 .-1.39)$ & \\
\hline
\end{tabular}

$*$ P-value $<0.05 ; * *$ P-value $<0.01$;

${ }^{\mathrm{a} R R}$, rate ratio; ${ }^{\mathrm{b}} \mathrm{CI}$, confidence interval; ${ }^{\mathrm{c} B M W}$, Brazilian minimum wages.

Source: Authors.

Table 3 presents the multilevel Poisson regression models. In model 2, the variables age, ethnicity and years in education were associated with dental caries outcome. White women had higher averages of DMFS compared to participants of other ethnicities. Pregnant women who did not finish primary education, or who were older (over 30 years old) also presented higher averages of DMFS. Behavioral variables were included in model 3, and the mean DMFS was statistically higher in pregnant women who smoked (rate ratio [RR] 1.41; 95\% CI 1.25-1.57). Furthermore, women who smoked during pregnancy had 41\% higher averages of DMFS. In model 4, oral measurements were added. Pregnant women who self-rated their oral health as poor 
Research, Society and Development, v. 10, n. 1, e32810111226, 2020

(CC BY 4.0) | ISSN 2525-3409 | DOI: http://dx.doi.org/10.33448/rsd-v10i1.11226

or very poor had higher mean DMFS (RR 1.21; 95\% CI 1.10-1.32). In addition, the presence of dental plaque at $\geq 15 \%$ sites were also associated with a higher average of DMFS.

\section{Discussion}

This study supports the hypothesis that psychosocial and behavioral factors influence the average number of dental caries in pregnant women. Poor self-ratings of oral health and smoking were also found to have a negative association with the average of DMFS during pregnancy. Our findings also suggested that higher age, fewer years in education, and dental plaque at $\geq 15 \%$ sites also influenced the average of DMFS. 
Table 3. Adjusted association of individual variables with mean of DMFS, determined using multilevel Poisson regression.

\begin{tabular}{|c|c|c|c|c|}
\hline Variables & $\begin{array}{c}\text { Model 1 } \\
\operatorname{IRR}^{\mathrm{e}}(95 \% \mathrm{CI})^{\mathrm{f}}\end{array}$ & $\begin{array}{c}\text { Model 2 } \\
\text { IRR }(95 \% \text { CI })\end{array}$ & $\begin{array}{c}\text { Model 3c } \\
\text { IRR }(95 \% \text { CI })\end{array}$ & $\begin{array}{c}\text { Model 4 } \\
\text { IRR }(95 \% \text { CI })\end{array}$ \\
\hline \multicolumn{5}{|l|}{ Fixed component } \\
\hline Intercept & $9.62(7.91-11.71)$ & $6.33(5.10-7.85)$ & $6.70(5.41-8.30)$ & $0.55(0.40-0.76)$ \\
\hline \multicolumn{5}{|c|}{ Demographic and socioeconomic characteristics } \\
\hline \multicolumn{5}{|c|}{ Age } \\
\hline$<20$ years & & 1 & 1 & 1 \\
\hline $20-30$ years & & $1.24(1.09-1.40)^{*}$ & $1.15(1.01-1.30)$ & $1.18(1.04-1.34)$ \\
\hline$>30$ years & & $2.60(2.29-2.96)^{*}$ & $2.34(2.05-2.68)$ & $2.41(2.11-2.76)$ \\
\hline \multicolumn{5}{|l|}{ Ethnicity } \\
\hline White & & 1 & 1 & 1 \\
\hline Non-white & & $0.87(0.80-0.94)^{*}$ & $0.80(0.73-0.87)$ & $0.79(0.73-0.87)$ \\
\hline \multicolumn{5}{|l|}{ Education } \\
\hline$>8$ years of formal education & & 1 & 1 & 1 \\
\hline$\overline{<} 8$ years of formal education & & $1.31(1.20-1.44)^{*}$ & $1.25(1.14-1.38)$ & $1.25(1.13-1.37)$ \\
\hline \multicolumn{5}{|l|}{ Behaviors characteristics } \\
\hline \multicolumn{5}{|l|}{ Smoke } \\
\hline No & & & 1 & 1 \\
\hline Yes & & & $1.41(1.25-1.57)^{*}$ & $1.30(1.16-1.46)$ \\
\hline \multicolumn{5}{|l|}{ Frequency of dental attendance } \\
\hline Irregular & & & 1 & 1 \\
\hline Regularly & & & $0.96(0.87-1.06)$ & $0.99(0.89-1.09)$ \\
\hline \multicolumn{5}{|l|}{ Oral health measures } \\
\hline \multicolumn{5}{|l|}{ Self-perception of oral health } \\
\hline Excelent/good & & & & 1 \\
\hline Fair/poor & & & & $1.21(1.10-1.32)^{*}$ \\
\hline \multicolumn{5}{|l|}{ Dental plaque } \\
\hline$<15 \%$ of surfaces & & & & 1 \\
\hline$\geq 15 \%$ of surfaces & & & & $1.22(1.08-1.37)^{*}$ \\
\hline \multicolumn{5}{|l|}{ Random component } \\
\hline Deviance $=(-2$ loglikelihood $)$ & 3138.22 & 2771.19 & 2650.61 & 2614.16 \\
\hline
\end{tabular}


Poorer self-perception of oral health was associated with higher averages of DMFS. Poor health habits are known to lead to worse oral conditions including the development of dental caries which is a major cause of tooth loss and dental pain (Selwitz et al., 2007). Thus, the association of self-perception with actual oral health may be possible to explain as women may be able to sense the symptoms of poor oral health. In addition, physical and psychological changes, along with altered perceptions of well-being and physical functioning, may be worse during the later period of pregnancy (Hopkins et al., 2018).

In addition, it is generally expected that pregnant women have healthy habits and consequently a good self-perception of their health. However, numerous factors can affect self-perception and care in pregnant and postpartum women. Studies showed that during the gestational period, low social support and lack of effective psychosocial resources can increase anxiety, depression and maternal stress (Hopkins et al., 2018). These factors affect the perceptions and resources available to pregnant women, influencing how they cope with the various changes that occur in this period (Acharya et al., 2009) which in turn is closely related to well-being and self-perception of health.

Pregnant women who smoked had a higher number of DMFS. Smoking has been related to worse oral health outcomes in different populations (Tanner et al., 2015; Petersson et al., 2019). A study of women of childbearing age has shown that smoking may be a risk indicator for dental caries regardless of other lifestyle and socioeconomic variables (Tanner et al., 2015). Thus, the association between dental caries and smoking, or pregnancy as identified in this study, may be explained by a common underlying mechanism. Changes that occur during pregnancy may lead to reduced salivary flow (Leal et al., 2013), and some study have shown that smoking reduces the salivary flow rate Thomson et al., 2002). The change in salivary secretion can cause a decrease in oral acidity, which can increase the risk of cancer and the development of dental caries (Petrušić et al., 2015).

A cross-sectional study of 763 adolescents in North Brazil showed that young people who smoked were more likely to have dental caries (Silveira et al., 2015). Many studies also support that smoking is associated with dental pain and tooth loss (Bastos et al., 2008). In addition, young smokers were found to be more likely to have decayed or missing teeth than young people who did not smoke or who were former smokers (Petersson et al., 2019). Furthermore, individuals who did not smoke showed greater self-care with oral health when compared to smokers (Bastos et al., 2008).

Regarding socioeconomic characteristics, pregnant women with less years in education presented with a higher average of DMFS. Schooling has been used as a proxy for socioeconomic status. Several studies of different populations have shown an association between low socioeconomic status and occurrence of dental caries (Engelmann et al., 2016). Individuals with low socioeconomic status presented a higher risk of oral problems because they usually have poor oral hygiene habits and are not regular users of dental services. This result can be explained by the fact that they have fewer available resources, which can directly affect the manifestation of oral health diseases such as dental caries. In addition, a higher level of education has been associated with better health knowledge and family income, which may facilitate access and use of dental services during pregnancy (Rossel et al., 2013).

Older pregnant women presented the highest averages of DMFS. This result is in agreement with another study (Tonello et al., 2007), and highlights the fact that incidence of caries increases with age (Tonello et al., 2007). In this context, these findings can be explained by cumulative experience and exposure to risk factors during the individual's life. Some researchers also report that younger pregnant women are more receptive to and interested in adopting good habits and behaviors in the gestational period to improve their health and the baby's health.

Considering the clinical conditions, the presence of dental plaque in $\geq 15 \%$ of sites was directly associated with a higher average of DMFS, a finding which is supported by previous studies (Tonello et al., 2007). Bacterial plaque along with a susceptible host, sugar exposure, and poor oral hygiene are key components of caries development. As plaque a multifactorial disease, these factors alter the appearance and severity of the problem, which may explain the biological relationship between the presence of plaque and the occurrence of dental caries. 
This study has some limitations. This is a cross-sectional study, so the data does not allow the establishment of a causeeffect relationship between the independent variables and the occurrence of dental caries. In addition, some data were selfreported by pregnant women, which may cause information bias. However, this study also has strengths. This study considered the influence of different factors during pregnancy using a hierarchical and multilevel approach. Understanding the relationship of factors at different levels is fundamental to the planning of health policies aimed at reducing oral diseases and improving quality of life, especially in the pregnant population. This is a particularly important population to consider since problems in this period are crucial for the health of both the pregnant woman and her baby. Future studies should explore longitudinally the relationships between different harmful behavioral factors in dental caries in pregnant women and children throughout their childhood. Intervention studies focusing on the prevention of harmful behavior during this period are also encouraged.

\section{Conclusion}

Our results suggest that smoking and poor self-ratings of oral health are related to a greater average of DMFS in pregnant women. Older age, ethnicity, fewer years in education, and the presence of dental plaque also influenced the averages of DMFS. This information is fundamental for the improvement of oral health promotion strategies and quality of life in pregnant women. Contributors' Statement: Ms Bolsson designed the study, drafted and revised the manuscript. Ms Knorst designed the study, designed the data collection instruments, collected data, carried out the analyses, drafted and revised the manuscript. Ms Maroneze designed the study, collected data, drafted and revised the manuscript. Ms Casarin designed the study, designed the data collection instruments, collected data and revised the manuscript. Dra Dotto and Dra Zimmermann conceptualized and designed the study, coordinated and supervised data collection and critically reviewed the manuscript. All authors approved the final manuscript as submitted and agree to be accountable for all aspects of the work.

\section{References}

Acharya, S., Bhat, P. V., \& Acharya, S. (2009). Factors affecting oral health-related quality of life among pregnant women. International Journal of Dental Hygiene 7:102-7.

Bastos, J. L., Gigante, D.P., \& Peres, K. G. (2008). Toothache prevalence and associated factors: a population- based study in southern Brazil. Oral Diseases $14,320-6$.

Bianchini, B. V., Maroneze, M. C., Timm, M. S., Dos Santos, B. Z., \& Dotto, P. P. (2020). Prevalence of Alcohol and Tobacco Use and Perceptions Regarding Prenatal Care among Pregnant Brazilian Women, 2017 to 2018: A Mixed-Methods Study. Maternal and Child Health Journal, 24(12), 1438-1445.

Codato, L. A. B., Nakama, L., Junior, L. C. \& Higasi, M. S. (2011). Dental treatment of pregnant women : the role of healthcare professionals. Ciência e Saúde Coletiva 16(4):2297-2301.

Engelmann, J. L., Tomazoni, F., Machado, M. D., \& Ardenghi, T. M. (2016). Association between Dental Caries and Socioeconomic Factors in Schoolchildren - A Multilevel Analysis. Brazilian Dental Journal 1, 27:72-8.

Hopkins, J., Miller, J. L., Butler, K., Gibson, L., Hedrick, L., \& Boyle, D. A. (2018). The relation between social support , anxiety and distress symptoms and maternal fetal attachment. Journal of Reproductive and Infant Psychology 6838:1-12.

Kale, P. L., Fonseca, S. C., Silva, K. S., Rocha, P. M. M., Silva, R. G., Pires, A. C. A. Cavalcanti, M. D. T., Costa, A. J. L., \& Torre, T. Z. G. (2015). Smoking prevalence, reduction, and cessation during pregnancy and associated factors: a cross-sectional study in public maternities. BMC Public Health 15:406.

Lamarca, G. A., Leal, M. C., Leao, A. T. T., Sheiham, A. \& Vettore, M. V. ( 2012). Oral health related quality of life in pregnant and post partum women in two social network domains; predominantly home-based and work- based networks. Health Qual Life Outcomes 10(1):5.

Leal, A. D. O, Rolim, J. I. A, Muniz, I. A. F., Muniz, I. A. F. \& Farias, I. A. P. (2013). Study of salivary parameters' study of pregnant women. Odontologia Clínico-Científica, 2013; 12(1):39-42.

Melo, N. S. F. O., Ronchi, R., Mendes, C. S., \& Mazza, V. A. (2007). Hábitos alimentares e de higiene oral influenciado à saúde bucal da gestante. Cogitare Enfernagem 12(2):189-97.

Moimaz, S. A. S., Rocha, N. B., Garbin, A. J. I., Garbin, C. A. S., \& Saliba, O. (2016). Influence of oral health on quality of life in pregnant women. Acta odontologica latinoamericana 29(2):186-93. 
Research, Society and Development, v. 10, n. 1, e32810111226, 2020

(CC BY 4.0) | ISSN 2525-3409 | DOI: http://dx.doi.org/10.33448/rsd-v10i1.11226

Moise, I. K. (2019). Alcohol use, pregnancy and associated risk factors: a pilot cross-sectional study of pregnant women attending prenatal care in an urban city. BMC pregnancy and childbirth, 19(1), 1-7.

Petersson, G. H., \& Twetman, S. (2019). Tobacco use and caries increment in young adult : a prospective observational study. BMC Research Notes 1-5.

Petrušić, N., Posavac, M., Sabol, I., \& Mravak-Stipetić M. (2015). The Effect of Tobacco Smoking on Salivation. Acta Stomatologica Croatica, 49, (4):309315 .

Rossel, F. L., Oliveira, A. L. B. M., Tagliaferro, E. P. S., Silva, S. R. C., \& Júnior, A. V. (2013). Impact of Oral Health Problems on the Quality of Life of Pregnant Women. Pesquisa Brasileira em Odontopediatria e Clínica Integrada 13(3):287-293.

Selwitz, R. H., Ismail, A. I., \& Pitts, N. B. (2007). Dental caries. The Lancet 369:51-9.

Silveira, M. F., Freire, R. S., Nepomuceno, M. O., Martins, A. M. \& Marcopito, L. F. (2015). Cárie dentária e fatores associados entre adolescentes do norte do Estado de Minas Gerais: uma análise hierárquica. Ciência e Saúde Coletiva 20 (11):3351-64.

Solar O., \& Irwin A. A Conceptual Framework for Action on the Social Determinants of Health. Soc Determ Heal Discuss Pap 2 (Policy Pract [Internet]. 2010;79

Tada, A., \& Hanada, N. (2002). Sexual differences in smoking behaviour and dental caries experience in young adults. Public health 116, 6:341-346.

Tanner, T., Päkkilä, J., Karja-lainen, K., Kämppi, A., Järvelin, M-R., Patinen, P., Tjäderhane, L. \& Anttonen, V. (2015). Smoking, alcohol use, socioeconomic background and oral health among young Finnish adults. Community Dentistry Oral Epidemiology 3,406-14.

Thomson, W. M., Spencer, A. J., Slade, G. D. \& Chalmers, J. M. (2002). Is medication a risk factor for dental caries among older people ? Community Dentistry Oral Epidemiology 30, 224-32.

Tonello, A. S., Zuchieri, M. A. B. O. \& Pardi, V. (2007). Assessment of oral health status of pregnant women participating in a family health program in the city of Lucas do Rio Verde - MT. Brazilian Journal of Oral Science 6(20):1265-8.

Toquinto, S. M., Berglas, N. F., McLemore, M. R., Delgado, A., \& Roberts, S. C. (2020). Pregnant Women's Acceptability of Alcohol, Tobacco, and Drug Use Screening and Willingness to Disclose Use in Prenatal Care. Women's Health Issues, 30(5), 345-352.

World Health Organization [homepage]. (2013). Oral health surveys: basic methods. (5th ed.), 2013 https://www.who.int/oral_health/publications/9789241548649/en/ 